\title{
Effect of Feeding Regimen on Relationship between Carcass Measurements, Slaughter Weight and Hot Carcass Weight of Sudanese Desert Goats
}

\section{M.O.Mudalal ${ }^{1}$ \\ I. Bushara² \\ Dafalla M. Mekki ${ }^{3}$ \\ EIGazafey Besheer ${ }^{4}$ (D) \\ S.A.Babiker ${ }^{5}$}

,2,3 Department of Animal Production. Faculty of Natural Resources and Environmental Studies, University of Kordofan El-Obied, Sudan.

${ }^{4}$ Faculty of Medicine, University of ELdaein, Sudan.

${ }^{5}$ Faculty of Animal Production, University of Khartoum, Khartoum, Sudan

( Corresponding Author)

\begin{abstract}
The study was conducted to determine the effect of feeding diets, on growth performance and relationship between carcass measurements, slaughter weight and hot carcass weight, of 72 intact male desert bucks divided randomly into three groups; each group ( 24 males), the animals were slaughtered according to halal standard procedures. The results obtained indicated that correlation coefficients between slaughters weight and carcass measurements were significantly higher $(\mathrm{P}<0.01)$ and positive. In free grazing group correlation coefficients between hot carcass weight and carcass measurements were significantly $(\mathrm{P}<0.01)$ and positive. Also the relationship between slaughters weight and carcass measurements was significant and positive except internal chest length. In the group that grazing and supplemented with diets showed positive and significantly $(\mathrm{P}<0.01)$ correlation coefficients between hot carcass weight and carcass measurements and between slaughters weight and carcass measurements were significant and positive except carcass length. The zero grazing groups obtained non not significant correlation coefficients between hot carcass weight and carcass measurements except slaughter weight and external chest length.
\end{abstract}

Keywords: Goat, Carcass measurements, hot carcass and slaughter weights.

\section{Contents}

1. Introduction.

2. Materials and Methods

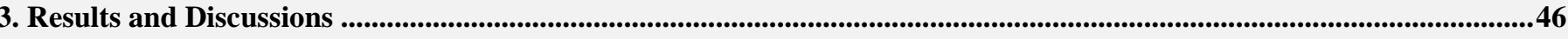

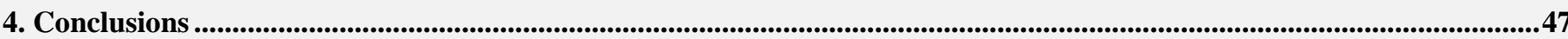

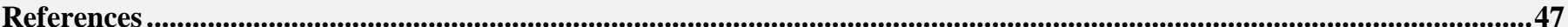

Citation | M.O.Mudalal; I. Bushara; Dafalla M. Mekki; ElGazafey Besheer; S.A.Babiker (2016). Effect of Feeding Regimen on Relationship between Carcass Measurements, Slaughter Weight and Hot Carcass Weight of Sudanese Desert Goats. Agriculture and Food Sciences Research, 3(1): 45-48.

DOI:

$\operatorname{ISSN}(\mathbf{E})$ :

ISSN(P):

Licensed:

Contribution/Acknowledgement:

Funding:

Competing Interests:

Transparency:

History:

Ethical:

Publisher: 10.20448/journal.512/2016.3.1/512.1.45.48 Crossref 2411-6653

2411-6653

This work is licensed under a Creative Commons Attribution 3.0 License $(\mathrm{cc}) \mathrm{EY}$

All authors contributed to the conception and design of the study.

This study received no specific financial support.

The authors declare that they have no conflict of interests.

The authors confirm that the manuscript is an honest, accurate, and transparent account of the study was reported; that no vital features of the study have been omitted; and that any discrepancies from the study as planned have been explained.

Received: 25 May 2016/ Revised: 15 June 2016/ Accepted: 20 June 2016/ Published: 2 July 2016

This study follows all ethical practices during writing.

Asian Online Journal Publishing Group 


\section{Introduction}

The goat population of Sudan is mostly located in smallholder farming areas, and their function is the production of meat. The traditional production system is extensive, with grazing on natural grassland with herbs, shrubs and forest and with little or no feed supplementation and this is mainly based on natural, unimproved savannahs, which lead to poor animal performance [1,2]. Goats are prominent browsers for herbs [3]. If herbs used in the diets of animals could have significant impact on feed intake, meat quality and composition [4-6]. The presence of high levels of herbs in feed have been reported to be responsible for decreased feed intake [6, 7] growth rate, feeding efficiency and live-weight gain [6,8]. The Carcass characteristics and meat quality are important criteria for consumers when it comes to making purchasing decisions. Carcass classification for conformation and fatness are the main parameters for determining the marker price. The linear carcass measurements, included length of carcass, depth of chest, length of leg and width of leg [9]. Many authors had showed that nutrition had significant effect on slaughter weight, hot carcass weight and fore and hind quarter [10]. Therefore, the producers are encouraged to continue producing according to the traditional systems and methods because the products are well accepted to the consumers. The feeding trials are ongoing in order to recommend supplementation strategies for the use of relatively expensive concentrates with tropical forage for feeding local goats raised for meat. The aim of the pilot study was to evaluate the effect of feeding regimen and castration on relationship between carcass measurements, slaughter weight and hot carcass weight.

\section{Materials and Methods}

\subsection{Study Area}

This study was conducted at El-Obeid Agricultural Research Station, North Kordofan State, Sudan.

\subsection{Experimental Animal's Management}

Seventy two male desert goats weighing $12.1 \mathrm{Kg}$ (aged 4-5 months) were divided randomly into three groups; each group content 24 males. Group one (free grazing only) on some dry grasses like Eragrotis turmula, Zornia glochiidiata and Cenphrus spp and browse the leaves of Ziziphus spina chritis, Balanite aegyptiaca and Calotropis purocera. Group two (grazing + concentrate supplement) and Group three (concentrate supplement only) ad libitum fed the experimental diet. The experimental diet given at a rate of $324 \mathrm{~g} / \mathrm{head} / \mathrm{day}$. Ingredients and chemical composition of experimental diet (Table 1). Live weight and external body measurements of each animal were recorded at the start of experiment, then weekly during the experiment, using spring balance. The animals were weighed in the morning at weekly interval for 12 weeks.

Table-1. Ingredients \% and Chemical Composition of the Experimental Feed Stuffs.

\begin{tabular}{l|l|l|l}
\hline Components & $\mathbf{\%}$ & Chemical composition & $\mathbf{\%}$ \\
\hline Sorghum grains & 30 & Dry matter (DM \%) & 98.6 \\
\hline Wheat bran & 38 & Organic matter (OM \%) & 87.7 \\
\hline Ground nut cake & 20 & Crude protein (CP \%) & 22.0 \\
\hline Ground nut hay & 10 & Crude fiber (CF \%) & 25.0 \\
\hline Sodium chloride & 1 & Ether extract (EE \%) & 12.0 \\
\hline Limestone & 1 & Nitrogen free extract (NFE \%) & 31.0 \\
\hline & & Ash (\%) & 08.0 \\
\hline & & Energy density (ME(MJ/ Kg DM) & 12.0 \\
\hline
\end{tabular}

\subsection{Slaughter Procedure and Data Collection}

Twelve animals from each group were slaughtered at 90 weeks. The animals were slaughtered according to halal standard procedures. The external and internal offals including gut content were weighed. Hot carcass, carcass halves were weight; the carcass was split along midline. The left half carcass were done according Owen [12] and cut into wholesale cuts, each cut was dissected according to Cuthbertson, et al. [13] into lean, fat, and bone.

\subsection{Statistical Analysis}

The data were statistically analyzed according to factorial experimental randomized design as a $3 \times 2$ (management Vs sex). Multiple range tests were used to compare the means using [14].

\section{Results and Discussions}

\subsection{Effect of Free Grazing on Slaughter Weights and Carcass Characteristics}

There is positive significant correlation between slaughters weight and carcass measurements Table (2). The highest correlation coefficients $(r=0.73$, $(\mathrm{p}<0.001)$ was found between slaughters weight and proximal hind leg length and between hot carcass and slaughter weight $(\mathrm{r}=0.63(\mathrm{p}<0.05)$. The slaughter weight and distal foreleg length exert lowest relationship and between hot carcass weight and internal chest length $(r=0.56,(p<0.05)$. This result was in agreement with the findings of Jibir, et al. [15] and Alexandre, et al. [1] who reported that the there is positive relationship between carcass measurements, slaughter weight and hot carcass weight were significant positive for animal depending on natural grazing. 
Table-2. Correlation Coefficients between Slaughter Weights, Hot Carcass Weight and Carcass Measurements (Free Grazing)

\begin{tabular}{l|l|l|l|l|l|l|l|l}
\hline & $\begin{array}{l}\text { Slaughter } \\
\text { Weight }\end{array}$ & $\begin{array}{l}\text { Carcass } \\
\text { Length }\end{array}$ & $\begin{array}{l}\text { Distal } \\
\text { Foreleg } \\
\text { Length }\end{array}$ & $\begin{array}{l}\text { Proximal } \\
\text { Foreleg } \\
\text { Length }\end{array}$ & $\begin{array}{l}\text { Distal } \\
\text { Hind Leg } \\
\text { Length }\end{array}$ & $\begin{array}{l}\text { Proximal } \\
\text { Hind Length } \\
\text { Leng }\end{array}$ & $\begin{array}{l}\text { Internal } \\
\text { Chest } \\
\text { Length }\end{array}$ & $\begin{array}{l}\text { External } \\
\text { Chest } \\
\text { Length }\end{array}$ \\
\hline $\begin{array}{l}\text { Hot carcass weight } \\
(\mathrm{Kg})\end{array}$ & $0.91^{* * *}$ & $0.60^{*}$ & $0.78^{* * *}$ & $0.61^{*}$ & $0.64^{* *}$ & $0.73^{* * *}$ & $0.56^{*}$ & $0.73^{* * *}$ \\
\hline $\begin{array}{l}\text { Slaughter weight } \\
(\mathrm{Kg})\end{array}$ & & $0.45^{\mathrm{NS}}$ & $0.63^{*}$ & $0.68^{* *}$ & $0.64^{*}$ & $0.73^{* * *}$ & $0.67^{* *}$ & $0.68^{* *}$ \\
\hline
\end{tabular}

Note: $* * * * * *$ and $*$ Significant at $\mathrm{P}<0.001, \mathrm{P}<0.01$ and $\mathrm{P}<0.05$ respectively, $\mathrm{NS}=$ non significant

\subsection{Effect of Free Grazing Plus Supplementation on Slaughter Weights, Hot Carcass Weight and Carcass Measurements}

The linear carcass measurements are indices of skeletal development and indirectly help to determine carcass conformation. Diet had significant and positive $(P>0.01)$ effect on relationship exert between slaughters weight and carcass measurements except internal chest length Table (3). The significant and highest positive correlation coefficients were found between slaughter weight and external chest length $(\mathrm{r}=0.85,(\mathrm{p}<0.001)$, between hot carcass weight and carcass measurements and between hot carcass weight and slaughter weight $(\mathrm{r}=0.96, \quad(\mathrm{p}<0.001)$ respectively. The values increased $(\mathrm{P}<0.01)$ progressively with inclusion of concentrate in the diet. The lowest correlation coefficients $(\mathrm{r}=0.65$, $(\mathrm{p}<0.01)$ between slaughter weight and distal foreleg length. and between hot carcass weight and distal foreleg $(\mathrm{r}=0.65,(\mathrm{p}<0.05)$. Generally the increase in weights of the main carcass cuts was related to the carcass weight increase due to availability of energy and protein in diets. Diet and slaughter weight may be the main causes of the differences with the results obtained by Owen [12] and Abdullah and Musallam [16]. The increase in weights of between hot carcass and slaughter weight with internal chest length was related to be not vary significantly. This results is online with studied of Oman, et al. [17] who reported that fed goats produced heavier slaughters weight and carcasses measurements than pasture goats.

Table-3. Correlation Coefficients between Slaughter Weights, Hot Carcass Weight and Carcass Measurements (Grazing + Supplemented Group)

\begin{tabular}{l|l|l|l|l|l|l}
\hline & $\begin{array}{l}\text { Slaughter } \\
\text { Weight }\end{array}$ & $\begin{array}{l}\text { Carcass } \\
\text { Length }\end{array}$ & $\begin{array}{l}\text { Distal Foreleg } \\
\text { Length }\end{array}$ & $\begin{array}{l}\text { Proximal Foreleg } \\
\text { Length }\end{array}$ & $\begin{array}{l}\text { Internal } \\
\text { Chest Length }\end{array}$ & $\begin{array}{l}\text { External } \\
\text { Chest Length }\end{array}$ \\
\hline Hot carcass weight $(\mathrm{Kg})$ & $0.96^{* * *}$ & $0.83^{* * *}$ & $0.65^{*}$ & $0.80^{* * *}$ & $0.55^{\mathrm{NS}}$ & $0.85^{* * *}$ \\
\hline Slaughter weight $(\mathrm{Kg})$ & & $0.84^{* * *}$ & $0.64^{*}$ & $0.82^{* * *}$ & $0.51^{\mathrm{NS}}$ & $0.79^{* *}$ \\
\hline
\end{tabular}

Note: ****,** and * Significant at $\mathrm{P}<0.001, \mathrm{P}<0.01$ and $\mathrm{P}<0.05$ respectively, $\mathrm{NS}=$ non significant

\subsection{Effect of Zero Grazing on Slaughter Weights and Carcass Characteristics}

Feed intake reported in (Table 4) followed the same trend as all correlation coefficients between slaughters weight and carcass measurements were significant and positive. Whoever, the highest correlation coefficients ( $\mathrm{r}$ $=0.87,(\mathrm{p}<0.001)$ exert between slaughter weight and external chest length, and between hot carcass weight and slaughter weight $(\mathrm{r}=0.96,(\mathrm{p}<0.001)$

The lowest correlation coefficients $(r=0.58$, $(p<0.05)$ between slaughter weight and distal hind leg length, and between hot carcass weight $(\mathrm{r}=0.60,(\mathrm{p}<0.05)$. All correlation coefficients between hot carcass weight and carcass measurements were not significantly except slaughter weight and external chest length which agree with Simela, et al. [18]. This is consistent with the results reported by Peña, et al. [19] and Marichal, et al. [20] who reported that the correlation coefficients between carcass measurements, slaughter weight and hot carcass weight were positive and significant. The variation between these results and that obtained by other authors may be due to differences in weight at slaughter and mature size of breed used.

Table-4. Correlation coefficients between slaughter weights, hot carcass weight and carcass measurements (zero grazing)

\begin{tabular}{l|l|l|l|l|l}
\hline & $\begin{array}{l}\text { Slaughter } \\
\text { Weight }\end{array}$ & $\begin{array}{l}\text { Carcass } \\
\text { Length }\end{array}$ & $\begin{array}{l}\text { Distal } \\
\text { Foreleg Length }\end{array}$ & $\begin{array}{l}\text { Internal } \\
\text { Chest Length }\end{array}$ & $\begin{array}{l}\text { External } \\
\text { Chest Length }\end{array}$ \\
\hline Hot carcass weight $(\mathrm{Kg})$ & $0.96^{* * *}$ & $0.52^{\mathrm{NS}}$ & $0.50^{\mathrm{NS}}$ & $0.35^{\mathrm{NS}}$ & $0.60^{*}$ \\
\hline Slaughter weight $(\mathrm{Kg})$ & & $0.54^{\mathrm{NS}}$ & $0.58^{*}$ & $0.76^{* *}$ & $0.87^{* * *}$ \\
\hline
\end{tabular}

Note: $* * * *, * *$ and $*$ Significant at $\mathrm{P}<0.001, \mathrm{P}<0.01$ and $\mathrm{P}<0.05$ respectively, $\mathrm{NS}=$ non significant.

\section{Conclusions}

Improvement in the plane of nutrition by supplementation of concentrates to grazing goats can promote faster daily live weight gain and increase slaughters weight and carcass measurements then have good and positive relationships between them, and thus enable the attainment of acceptable market weight at earlier age.

\section{References}

[1] L. Alexandre, A. Liméa, O. Fanchonne, N. Coppry, Mandonnet, and M. Boval, "Effect of forage feeding on goat meat production: Carcass characteristics and composition of creole kids reared either at pasture or indoors in the humid tropics," Asian-Aust. J. Anim. Sci., vol. 22, pp. $1140-1150,2009$.

[2] M. O. Mudalal, I. Bushara, M. M. Dafalla, and S. A. Babiker, "Effect of nutrition and castration on carcass measurements, wholesale cuts and carcass composition of male desert goats," Scientific Journal of Veterinary Advances, vol. 2, pp. 97-101, 2014.

[3] F. Hussain and M. J. Durrani, "Seasonal availability, palatability and animal preferences of forage plants in Harboi arid range land, Kalat, Pakistan," Pak. J. Bot., vol. 41, pp. 539-554, 2009.

[4] A. Priolo, D. Micol, J. Agabriel, S. Prache, and E. Dransfield, "Effect of grass or concentrate feeding systems on lamb carcass and meat quality," Meat Sci., vol. 62, pp. 179-185, 2002.

[5] I. N. Do Prado, J. A. Aricetti, P. P. Rotta, R. M. Do Prado, D. Perotto, J. V. Visentainer, and M. Matsushista, "Carcass characteristics, chemical composition and fatty acid profile of the longissimus muscle of bulls (Bos Taurus Indicus vs. Bos taurus Taurus) finished at pasture," Asian-Aust. J. Anim. Sci., vol. 21, pp. 1449-1457, 2008. 
M. Karami, A. R. Alimon, Y. M. Goh, Q. S. Awis, and M. Ivan, "Effects of dietary herbal antioxidants supplemented on feedlot growth performance and carcass composition of male goats," Am. J. Anim. Vet. Sci., vol. 5, pp. 33-39, 2010.

[7] P. Onanong, W. Metha, W. Chalong, W. Sadudee, and C. Anusorn, "Manipulation of ruminal fermentation and methane production by dietary saponins and tannins from mangosteen peel and soapberry fruit," Arch. Anim. Nutr., vol. 63, pp. 389-400, 2009.

[8] A. Priolo, G. C. Waghorn, M. Lanza, L. Biondi, and P. Pennisi, "Polyethylene glycol as a means for reducing the impact of condensed tannins in carob pulp: Effects on lamb growth performance and carcass and meat quality," J. Anim. Sci., vol. 78, pp. 810$816,2000$.

[9] H. De Boer, B. L. Dumont, R. W. Fomeroy, and J. H. Weniger, "Manual on E. A. A. P. R reference methods for the assessment of carcass characteristics in cattle," Livestock Production Science, vol. 1, pp. 15- 164, 1974.

[10] R. Bhuyan, K. K. Baruah, and P. C. Das, "Growth response and carcass characteristics of crossbred kids fed rations having different concentrate to roughage ratios," Indian Journal of Animal Nutrition, vol. 13, pp. 167-169, 1996.

[11] MAFF, Technical bulletin 33 - energy allowances and feeding systems for ruminants. London: HoMeS.0, 1976.
[12] J. E. Owen, "The meat producing characteristics of indigenous Malawi goats," Trop. Sci., vol. 17, pp. 123-138, 1975.

[13] A. Cuthbertson, G. Harrington, and R. J. Simth, "Tissue separation to assess beef and lamb variation," in Proc. Br. Soc. Anim. Prod. Symp. Aspect of Carcass Evaluation, 1972, pp 113-122. Edinburgh: Longman, 149 pp Goats. Revista Cubana de Reproduction Animal 3: 13-19. A.B. A.47, 4275, 1972.

[14] SPSS, Statistical package for social sciences. Chicago: SPSS Inc, 1999.

[15] M. Jibir, A. M. Isa, S. Garba, I. Jibrila, and A. B. Omojola, "Linear body measurements and slaughter characteristics of meat goats in the semi-arid zone of North-Western Nigeria," J. Anim. Sci. Adv., vol. 3, pp. 297-303, 2013.

[16] A. Y. Abdullah and H. S. Musallam, "Effect of different levels of energy on carcass composition and meat quality of male black goats kids," Livest. Sci., vol. 107, pp. 70-80, 2007.

[17] J. S. Oman, D. F. Waldron, D. B. Griffin, and J. S. Savell, "Effects ofbreed type and feeding regimen on goat carcass composition, retail selflife, sensory and chemical characteristics," Master' s Theseis Texas A \& M University. College Station, Texas, 1995.

[18] L. Simela, L. R. Ndlovu, and L. M. Sibanda, "Carcass characteristics of the marketed Matebele goat from South-Western Zimbabwe," Small Rum. Res., vol. 32, pp. 173-179, 1999.

[19] F. Peña, J. Perea, A. García, and R. Acero, "Effects of weight at slaughter and sex on the carcass characteristics of Florida suckling kids," Meat Science, vol. 75, p. 543-550, 2007.

[20] A. Marichal, N. Castro, J. Capote, M. J. Zamorano, and A. Argüello, "Effects of live weight at slaughter (6, 10 and $25 \mathrm{~kg})$ on kid carcass and meat quality," Livestock Production Science, vol. 83, p. 247-256, 2003. 